\title{
LOGICAL QUESTIONS CONCERNING THE CONCEPT OF THE EMPIRICAL SELF
}

JEREMY WALKER McGill University

About the concept of the empirical self one can make inquiries of two kinds. (I) One can inquire if it is a possible concept. Here one inquires (a) whether the words 'the empirical self' refer to some entity that satisfies the criteria for being classed as a concept: and (b) whether, if so, they identify a concept that can exist as a concept for us. (a) I do not know what are the general conditions that determine whether or not a phrase refers to a concept. I do know, however, that one necessary condition is that there must be no logical inconsistency attached to the phrase. Hence, if the words 'the empirical self' refer to a possible concept, it must not be logically inconsistent to predicate empiricality and selfhood of one \& the same entity. Most of my paper discusses this question, in its various details. (b) Traditionally one has distinguished between a priori concepts and empirical concepts. Although this distinction is not clear, one can at least say that what distinguishes an alleged $a$ priori concept is that its content is not, or not wholly, given by experience, even though it may be occasioned by experience. I am enough of an empiricist to believe that it is a necessary truth that there can be not a priori concepts of empirical entities. Hence, the concept of the empirical self must be an empirical concept. To show that it is a possible concept-for-us is therefore to show that the content of this concept is derivable from experience. (It need not be ordinary, average experience). If one could establish points (a) \& (b), one would have established that the empirical self is a possible concept. 
(II) One can also, and independently, inquire whether this concept - assuming it to be possible- has any actual application(s). It does not follow from the fact -if it is onethat it is a possible concept, that it is a concept which actually applies to any existing entity. Here I discover an aporia. Let us suppose, as is logically possible, that the concept of the empirical self, while itself a possible concept, is at the same time empty: there are no empirical selves. Now let us consider the logical status of this latter proposition. If we say that it is ibself necessarily true, we seem to be implying that the concept of the empirical self is logically inconsistent, which contradicts an assumption we have made. Hence we are forced to construe this proposition as, if true, contingently true, and hence the record of an empirical fact. But it appears to me that when philosophers (since Hume) have claimed that there is (is not) an empirical self, they have intended their claims to have the status of philosophical truths. Hume's observation concerning his alleged 'self' was not intended merely as a piece of contingent autobiography. Hence I am forced to suppose that philosophers have intended their claims as a priori, hence necessary, truths. If so, the normal logical process of (I) establishing the possibility of a concept and then (II) independently establishing its application (if any) has not been conceived as itself applicable in the case of this particular concept that we are examining.

In order to be classifiable as an 'empirical self, any entity must satisfy two criteria: (A) It must be classifiable as 'empirical', that is, as an empirical entity, (B) It must be classifiable as a 'self'. These form necessary, but by no means sufficient, conditions. One further, extremely important, condition can be seen if we reflect that the use of the phrase 'the empirical self' implies - as Russell showed - that there is precisely one empirical self. This, if strictly construed, implies that there is no more than one empirical self in the whole world. However in normal context it clearly implies 
only that just on empirical self is to be assigned to each person, or each individual human being. It is not sufficient, therefore, to show that each person possesses an empirical self -assuming we could show that. In addition, one must show that no person prossesses a plurality of such selves. Ordinarily, I think, this part of the question is simply begged, as when philosophers or psychiatrists refer to the self'. They do not justify the phrase.

(A) It is not easy to say what conditions must be fulfilled in order that an entity be classifiable as 'empirical' - as an empirical entity. Let us begin by remembering that for the predicate empirical to have sense (content), there must be some other contentful predicate with which it is logically contrasted: some contentful predicate of the general form non-empirical. This may be a predicate such as a priori, or transcendental. But no philosopher who regards all predicates of the latter range as empty of sense can regard the predicate empirical as having sense.

I shall say that at least two conditions that must be fulfilled in order that an entity be classifiable as 'empirical' are (i) that it be identifiable by empirical methods, \& (ii) that it be identifiable with some empirical entity - even if the latter be only itself. But I find that I cannot say what are themselves to be identified as empirical methods. I do not know what criteria must be fulfilled in order that we be fully justified in speaking of empirical methods. Certainly 'empirical methods' enither means nor refers to the same as does 'methods of empirical science'. If I say that tables are empirical entities then I am implying that they are entities such that they can be identified as tables by empirical methods. But we do not identify tables as such by the methods of any empirical science. Looking at the table from a variety of viewpoints, touching it, rubbing it, knocking upon it, and lifting it, are perfectly standard empirical methods for identifying it as a table. Further, it appears to me that we may 
speak of internal observation as a kind of empirical method of identification, as, for example, when I suffer from a tooth. ache but have not yet put my mind to locating the precise tooth in which I am suffering. Putting my mind to this task is an empirical method, as far as I can see. Yet concerning the idea of 'verification by internal observation' there are many notorious problems which Wittgenstein, among others, has exposed: \& it is well to remember that some philosophers would not even agree with me that there does, or can, occur any such phenomenon as 'internal observation'. Third, 'em. pirical' in 'empirical method' does not refer to 'perceptual', if perceptual methods are supposed to be contrasted with intellectual methods. That an entity can be identified only by what may be loosely called intellectual methods does not prove that it is not an empirical entity - does not prove, for example, that it is a transcendental entity. Hence, if it were a fact that the self could be identified only by intellectual methods (thinking, reasoning, speculating, etc.), that would not have any tendency to prove that the self so identified was a transcendental self. The justification for this claim is that a cardinal technique employed in constructing the empirical sciences is the use of the intellect in the formation of theoretical concepts and the construction of theories. Such sciences are not less empirical since they are also theoretical. I must admit, though, that the theories \& theoretical constructs of the empirical sciences are empirically validated, in some sense, by means of their logical connexions with concepts immediately descriptive of actual phenomena of observation \& measurement. Such theoretical concepts, then, may be called also empirical only insofar as they play an essential role in the explanation of such phenomena. I do not, therefore, argue that because 'the empirical self' is a 'theoretical concept' -if it is - it is therefore also an empirical concept. To show this, it has to be shown in addition how this concept functions as an essential part of some general schema of explanation of certain phenomena. I believe this intention underlies the 
employment of this, and related, concepts by most psychol. ogists, psychiatrists, and certain sociologists.

(B) What criteria must an entity fulfil in order to be classifiable as a self? I should begin by observing that the peculiar difficulty one meets in answering this question is due to the fact that, in a certain sense, there is no concept of the self. What I mean by this is that the concept of the self is a philosophers' concept: an invented concept. There are possibly as many different concepts of the self as there are philosophers who have philosophized about the self. In a certain sense, therefore, the answer to the question I have posed can only be arbitrary. Nevertheless, I think it is possible to identify four criteria which must be fulfilled by any concept of the self, if that concept is to be identifiable as a concept of the self. However, if someone replies that I am doing no more than specify my own concept of the self, in claiming these four criteria as essential, I do not clearly yet know how to answer him.

In order to be a self an entity must (1) be continuous over a certain period of time, (2) possess an individual identity - be individuatable-, (3) suffer change, or be capable of suffering change, of a certain type, over a period of time, \& (4) possess consciousness at specifiable times and over certain periods of time. Notice the reference to time. My criteria clearly imply that there can be no such entity as $a$ non-temporal self, even abstracting from the question of the logical possibility of such a concept. Notice also that in my definitions I abstract from the question of the mortality of the self or its possible survival of death. (I will, however, later say some things that bear on this question.) I may be accused, thus, of begging the question of the possibility of the existence of a personal deity - a god with self-hood. This accusation is unfounded. My criteria permit the existence of either (a) a temporal, \& extremely long-lived, deity, or (b) a temporal, \& infinitely long-lived, deity. It is only when the 
concept of eternity is not construed as the concept of infinite time that my criteria rule out the possibility of the existence of a deity who is both eternal and possesses self-hood: but despite the fact that some thinkers have employed a 'nontemporal' concept of eternity (e.g. Kierkegaard), I cannot find that I understand them.

(1) To be a self, an entity must necessarily be continuous in its existence (persistence) over a certain period of time. That is to say, no entity whose existence in time is not continuous, for example instantaneous, can possibly be a" 'self'. This is because the concept of the self is the concept, inter alia, of a principle for assigning different phenomena to one 'focus', or, more perspicuously, a principle for assigning different events to one 'focus'. It is a principle for collecting events: and, perhaps, also a principle for individuating events. I am here speaking of its logical function. When I speak of the concept of the self as the concept of a certain principle, I wish to imply that this principle is to be taken as nonphenomenalistic: the self is 'more' than that bundle of events to which it serves as principle of unity or collection. It cannot be defined extensionally, by reference to these events alone. (This claim does not imply, however, that principle which is the self in its logical aspect is a noumenal, or transcendental, existent. It may, for example, be an entity which can be inferred inductively from those events whose principle it is - as it perhaps appears in the work of Ryle.) No instantaneous entity, then, can be a 'self', since where an entity is instantaneous it appears to me impossible to distinguish between its essential \& accidental attributes: or, to express the point otherwise, impossible to distinguish a principle of unifying assignation from the events so unifyingly assigned. And in the case of the self, I am implying, these distinctions must be capable of being made. ( $\mathrm{I}$ am aware of a deep insuf. ficiency in these arguments: I do not know how to remedy it.)

To say this is, I think, something that can profitably be expressed by saying that, in my conception, the self must 
be understood as having a substantial role, in some sense of 'substance'. For we cannot speak of substance without speaking of essential attributes, \& of the distinction between essential \& accidental attributes. (It is at this point that the contemporary notions of roles \& role-playing, in their relations to the self, become relevant.)

To claim that the self must be continuous over a certain period of time is, however, not perspicuous. For there are very many varying concepts of continuity over time, or of temporal continuity. Now we may admit that the mode of continuity of the self, whatever it is, cannot so to speak transcend the mode of continuity of time itself. (I cannot argue for this: it seems clearly true to me.) Thus, for example, if time is densely ordered, the self cannot possess Dedekindian continuity: if time is merely discrete, the self cannot possess density, and so on. On the other hand, it appears to me that, whatever the mode of continuity of time itself, the self cannot possess a mode of continuity which is, so to speak, inferior to that of time. In fact time \& the self must possess exactly the same sort of continuity. Although this appears to me to be true, it does not solve the problem with which we are faced, since it is notorious that there is no one self-evidently true model for time. That is to say, it does not appear possible (yet) to decide what kind of logical series is instanced by time. Hence we cannot say what kind of continuity over time the self possesses (if there are any selves). Nevertheless, I want to express my doubt whether any 'punctiform' concept of continuity - even that of Dedekindian continuity, which is punctiform, in the sense that it is instanced by the series of the real numbers- can possibly fit the concept of the self. I want to express, in as tentative a manner as I know how, my feeling that the concept of the self is the concept of an entity which possesses some kind of 'absolute', non-punctiform, continuity. I must again admit that I do not know clearly what these words mean.

Here I must introduce a further consideration whose bear- 
ing puzzles me. It is a notorious feature of human existence that our conscious life has periods of intermission: of sleep and unconsciousness, for example. One might therefore argue, if one made the strong claim that the self as such necessarily possesses consciousness, that during such periods the self ceases to exist. Indeed, on that assumption, one must so argue. But it appears to me unnatural to say that the self ceases to exist during periods of sleep \& unconsciousness, for example. On the other hand, if someone wished to say that it is unnatural to say that during these periods the self still at that time exists, I do not know what to say to him. In fact I am forced to suppose that the question. "When does the self exist, during life?", is a nonsense question. But I do not see why.

I find at this point an even odder aporia in my mind. If we consider for a moment the hypothesis that the self possesses a recurrent mode of temporal existence - that although there are periods of intermission in its existence, still the same self turns up again next morning, so to speak-, I find myself inclining to say that it is as if between one 'occurrence' of the self \& another no time had elapsed. It is as if, although the self really ceased to exist during the intermission between the two periods of its occurrence, nevertheless during that intermission it continued to exist in some non-temporal manner. There may be at least three considerations which drive me to say such a peculiar thing. (i) Generally, I find it impossible to admit that an entity can exist in a genuinely discontinuous manner. It may be said that there is no problem: the thing, $x$, goes out of existence at one moment of time $t$, and reappears in existence at another later moment of time $t$ '. There is admittedly the problem of providing satisfactory criteria for identifying the thing which reappeared in existence at $t$ ' with the thing that disappeared at $t$. However, I cannot find that I can make sense of the ontological picture drawn in this manner. (ii) There is the phenomenon of memory. This is well known to be central to the problem 
of the self, but in this connexion the phenomenon that impresses me is our normal capacity, on waking or recovering from unconsciousness, for example, to remember the events that preceded that interruption of our consciousness. This is not solved by simply remarking that there are persistent conditions of the brain \& nervous system which in some unknown manner contain our memories. The problem is how the consciousness of a certain past event can recur at a later time, after a period of the total interruption of the conscious. ness, \& I must confess this problem puzzles me totally. Memory relates to my aporia in another way, too. If one analyses the concept of memory as the concept of a mode of consciousness of some past event, then granted that past events are genuinely past, i.e. no longer exist, I find myself puzzled to conceive how a consciousness existing at a certain time $t^{\prime}$ can embrace an event that occurred at some other time $t$. A further difficulty is that in remembering something, it appears to me, we in a certain sense experience that past event as present. It is as if time did not exist for memory. (iii) Leaving these aporiai aside, I find that the third - and relatively simple-, consideration that influences me is that selves must be ascribed to persons, and while consciousness certainly suffers lapses, the person who is the bearer of this consciousness certainly continues to exist during his/her periods of unconsciousness.

I now leave the subject of continuity, in order to turn to the concept of the identity of the self.

(2) The empirical self must possess an identity, and more particularly an individual identity. (Atoms of a certain element each possess identity without, however, possessing individuality.) Therefore it is necessary that there be criteria for individuating selves. These criteria play a dual role. (i) They serve to individuate each self as the particular self it is. (ii) They serve, at the same time, to identify it distinguishingly from all other selves.

I here put forward a thesis: that the self is individuated 
by its acts. One might think that it is better to say that the self is individuated by the acts of the person - the person to whom the self belongs. I do not accept this as the equivalent of my version, however. For it seems to me that there can be a person \& the acts of that person even where there is no self that can be adscribed to that person - for example, in certain disordered psychological conditions. It is only when a person has a self that his/her acts can serve to identify his/her self. I understand 'acts' in a rather strange way. I do not only include the overt bodily behavior of the person in question, including his/her speech. I wish to include also that person's thoughts, wishes, unconscious wishes, dreams, parapraxes, etc. All of these are to be counted as 'acts of the self' by my criterion. Notice that it is from its identification by its acts that the self derives its empirical content - it is from the fact (if it is a fact) that the concept of the self is the concept of an entity for whom the identifying criteria are provided by empirical 'acts' that it follows that it is itself necessarily the concept of an empirical entity.

In including thoughts, wishes, unconscious wishes, etc., under the category of 'acts', I am merely supposing that to know someone is to know what his/her outer \& inner life is. This is what we normally do suppose. It is important, however, to avoid a mistake in interpreting this thesis. The mistake to which I am referring is that of assuming that the relationship of outer to inner is identical with the relationship of the empirical to the transcendental. That this is a mistake has, I think, been sufficiently shown by the work of Wittgenstein and Ryle, so I need not go further into it here. Now I earlier claimed a non-phenomenalistic account of the self. We have, therefore, to resist a phenomenalistic account of the relation of the self to its acts. What is the proper relationship? My view is extremely unsettled, but I wish to propose that the relation of the self to its acts is an instance of the general relation between Essence and Appearance. Essence and Appearance are definitely not here to 
be construed in a Platonistic sense: of that I am clear. Whether the relationship is to be construed in a Hegelian, or an Aristotelian, sense I am not in the least clear. I earlier spoke of the self as a 'substance' \& using this term I was conscious, and wished you to be conscious, of the Aristotelian reverberations of the term. I do not claim to understand what Aristotle means by essence or substance (to ti en einai, ousia), but his account in the Metaphysics impresses me as bearing the marks of convincing truth. Again, although I find myself in almost complete darkness when reading Hegel's account of the relation between inner and outer (in the Phenomenology), it impresses me as saying something which, if could understand it, would be convincingly true.

There is one difficulty -a problem of practice as well as of theory- which I should like to mention before leaving this topic. In proposing that it is in the acts of the self that the self is identified, it appears to me to be necessary to be able to distinguish between those acts that are essential attributes of the self, so to speak - that is to say, if we can speak of acts as attributes-, and those that are its accidental attributes. This is a distinction that finds some place in everyday life. It also plays an important role in our thinking about ourselves and our everyday behavior. But I do not know how we can distinguish non-circularly between the essential $\&$ the accidental attributes, or acts, of the self.

(3) The empirical self must suffer change, or be capable of suffering change, over a given period of time. This implies three things. (a) The self must be allowed to grow over time. (b) It must, perhaps, be allowed to grow into a self from a condition of non-self (pre-self, rudimentary self). (c) It must be permitted to develop over time. There seem to me two reasons for saying this. The first is that the ordinary concept of the self is of something which does typically develop over the course of a human life. The second is an a priori argument, over whose force I am entirely doubtful. The proof is from the consideration of the concept of an essentially static 
self. Allowing, what I have not yet argued but will come to bellow, that the self is essentially self-conscious, this is the concept of an entity which possesses self-consciousness but is, at the same time, without the possibility of change due to self-consciousness. That self-consciousness allows the possibility of change appears to me to be more than a contingent truth. I find the idea of a being who possessed self-consciousness, but whose self-consciousness was powerless to act as a cause, or occasion, for self-change, to be incomprehensible.

In order to discuss the question of the self's development, we must ask what criteria must be fulfilled, in general, for us to be able to say of any entity $X$ that it has developed into entity $Y$. For I take it that all development is of something into something - whether or not it is something else. The point of this is that we must be able to distinguish something's developing into something from its having changed into that thing. Set out in logical schema, to say that $X$ has changed into $Y$ appears to me to imply (i) that $X$ no longer exists, and (ii) that $Y$ is not $X-Y$ is different from, other than, $X-Y$ cannot be identified as $X$. If change is other than development, these two necessary conditions of change will not, in general, be necessary conditions of development. Indeed, it seems plausible that we reach the concept of development precisely by relaxing these two conditions. I say 'relaxing', rather than 'abandoning', since I am not sure that we can quite say, in interpreting the notion of development, that (i) $X$ still exists or that (ii) $Y=X$. For example, it does not seem to me that, considering the example of the acorn and the oak-tree, we can quite say (i) the acorn still exists 'in' the tree, or (ii) the oak-tree is, in a sense, the acorn. Nevertheless, it appears to me equally crass to say that there has been, so to speak, a complete lacuna of existence between the acorn and the tree, or that there is no principle leading us to assimilate the acorn and the tree. My present view is that we must say that $X$ and $Y$ are the same thing, but without converting this into the proposition: $X=Y$. In fact, there 
is no single variable term that we may substitute for the expression 'thing', nor for the phrase 'the same thing'. That proposition cannot be schematized logically. And we have to add, in order to make our proposition more perspicuous, that $X$ and $Y$ are the same thing at different stages of its development - 'its' development. Hence, it appears that the definition of the concept of development by means of a schematic criterion is liable to be circular, as is the implicit definition proposed above. More generally, it seems to me that formal logic does not, so to speak, quite fit such entities - developing entities. I must admit I have not pursued this matter deeply, and I am not aware of any work there may recently have been upon this problem. The answer is not to be found, I am sure, in trying to construct formal logics that reject the Law of Contradiction, or the Law of the Excluded Middle, since such attempts merely appear to me to be deeply confused.

Coming down to earth, we must next examine the criteria for the notion of 'the development of the self'. My only sug. gestion here is that we may identify these with the criteria for the development of the personality'. I do not know what the latter are. Does it follow that self = personality? I do not believe so: for I think that the relationship of the self to the acts performed by the person in question is not identical with the relationship of the personality of that person to his/her acts. But here is another point at which I have not pushed my analysis further.

Let us say three things in general about the criteria for self-development. (1) Some features can appear, others can vanish. (2) It follows, if we are to be able to speak of identity, that there must therefore be an identifiable continuity of features. (3) And there must, in addition, be a principle for linking new features to the old self. These are, in a way, quite general conditions for the application of the notion of development to anything whatever. But in respect of the concept of the self, I suggest that we should not do better than 
adopt, as a guiding light, the principle of potentiality \& actualisation of potentialities. Whether this is, so to speak, a natural actualisation, or a Hegelian actualisation involving the actualisation of self-consciousness, I am not certain. Nevertheless, I believe that the Aristotelian metaphysics still provides us with certain ideas that are useful, and perhaps indispensable, in these discussions.

If we identify the growth of a self from a non-self (a preself or rudimentary self) with its growth from a potential self, this may be a second place in our puzzles where such metaphysics is of assistance.

(4) That a self must possess consciousness that is temporal in both the sense that it exists at certain times and the sense that it exists over certain periods is, probably, the most important and most difficult of all these assertion concerning the concept of the empirical self.

I begin by making two assertions. (a) Unless a being possesses consciousness it cannot be conceived to possess a 'self' - at least an empirical self. (One might wish to hold that even a stone partook in the transcendental Self of the universe.) The proof of this proposition appears to me to be very short \& simple, but I am correspondingly doubtful of its validity, as of its power to convince. It is that if we consider the concept of a nonconscious being, we cannot assign to such a being a self, since we cannot more fundamentally assign to it an essential principle of individuality unless it is that essential principle of individuality which applies to organic beings. To sub-organic beings it appears to me that we cannot assign any such essential individuating principle. In fact, at this point it seems to me that we can assign substance, in a useful sense, only to such beings as are either organic or super-organic. However only the substantial principle of individuality of a super-organic - that is, an essentially conscious - being can be conceived under the category of self. It is to natural organic beings in particular that the Aristotelian category of substance applies: and I do not think 
that we can find in Aristotle any concept like the concept of the empirical self: not even the idea of psyche plays this role satisfactorily. (b) In the second place, I wish to assert that unless a being possesses self-consciousness, or more properly self-awareness, it cannot be conceived as possessing a self. Hence, although I am willing to grant that animals may have personalities, I will not allow them selves, except insofar as we may justifiably ascribe self-awareness to them.

Before proceeding, I wish to insert some reflexions here on the concept of substance in relation to conscious beings and organic but non-conscious beings. In the latter case substantiality may be assigned to a being on the grounds of an evident principle of unity's being operative in the various consecutive stages of that being's growth over time. This statement is completely formal, and does not begin to specify what kind of evident principle of unity is involved, or by what criteria it is to be identified in reference to various species of organic beings. What is, however, indubitably true, I think, is that here the principle of unity, whatever it is, is necessarily completely manifested in the various phenomena of the stages of growth. Hence I find that here there are no grounds for rejecting a phenomenalist interpretation of the 'essence' of such types of being. Contrast the phenomenon of conscious being. Here consciousness makes all the difference. For it allows a distinction - a gap- between the substantial principle and the phenomena. (Consider, for example, the familiar gaps between intention and action, thought and speech, the phenomena or hypocrisy, deceit, and self-deceit, and so on.) There are, therefore, in this case grounds for rejecting the phenomenalist analysis as giving an insufficient account of these familiar cases.

I have asserted that any being that possesses a self necessarily possesses self-consciousness. Notice that it is entirely illegitimate to argue from this proposition that the self is the consciousness of this being, or that the self is its self-consciousness. I do not therefore assert either of these last pro- 
positions.

If possession of a self necessitates possession of self-consciousness, does possession of self-consciousness necessitate possession of a self? It might be thought on inspection that this question resolved itself through an evident tautology. But I wish to reject the converse assertion, since it appears to me that the phenomena of the consciousnesses of children and schizophrenics (etc.) afford good grounds for saying that a being can possess self-awarness, of a kind, without being a genuine self. What is guaranteed, however, by possession of any mode of self-consciousness is that one is $a$ being of $a$ kind that normally has a self, and hence that, in a certain sense, one is also already potentially $a$ self. The sense of 'potentially' here is unusual: it does not necessarily refer forwards to the future, since the schizophrenic may be beyond the point of no return, so to speak. He is not now capable of ever becoming a genuine self. It is still true, however, that it is not impossible that he might (now) have had a self, and this is the sense of potentiality I mean.

Above I hastily rejected the idea that the self is to be identified with consciousness. I want to end by giving an argument to this effect. In general, I have earlier claimed, criteria for describing and identifying the empirical self are taken from behavior, in a broad sense which includes intentional performance. I do not accept behaviorism in any of its many logical forms: but I merely wish to point out that even if one accepts behaviorism in its weaker form ("There is consciousness, but its criteria are behavioral') one will still not be able to identify the self and consciousness. For if one tried to make this identification, there would remain no defence against phenomenalism, and no possibility of picking out from the mass of behavior such behavior as embodies consciousness, and is thus the 'essential' behavior of the self. Such selection would always necessarily remain quite arbitrary.

Let me end by putting my four criteria into a somewhat 
new light. I do this by recalling that I have earlier claimed that the concept of the empirical self is (formally) the concept of a principle for assigning certain phenomena -a certain selection of the relevant phenomena - to one 'focus'. (1) The question of the continuity of the self now becomes the question of the 'continuity' of a certain type of unifying, explanatory, principle of personal behavior. If we take this line, it is clear why I was so puzzled about the nature of the 'existence' of the self in its relation to time. It is well to be puzzled about the 'existence' of principles of explanation of temporal phenomena in their relation to time. (2) The ques. tion of the identity of the self becomes the question of providing criteria for identifying such a focussing, explanatory, principle of behavior. This illuminates my claim that the self is identified by its acts, and gives a new meaning to the view that the relation of the self to its acts is an instance -in some sense - of that of Essence to Appearance. (3) To say that the empirical self is essentially capable of temporal development now becomes the rather different claim that a certain principle of explanation is essentially capable of such development. Given an entity - a person- otherwise iden. tifiable independently of identifying his/her 'self' - whose behavior itself changes \& develops over time in some relatively coherent manner, we may well try saying that the fundamental cohesive principle of his/her behavior itself needs adaptation to fit the new circumstances. (4) If the self is a principle for assigning \& explaining the behavior of an essentially conscious being, it becomes immediately clear why there is a temptation to identify the self with this 'consciousness' itself, since in many cases the consciousness does serve an explanatory role in relation to the bodily phenomena. But not in all cases. 
Con relación al concepto empírico del yo hay dos tipos de preguntas posibles: (I) Se pregunta uno si es un concepto posible: (a) si las palabras 'el yo empírico' se refieren a alguna entidad que satisfaga los criterios para ser clasificada como 'un concepto', y (b) si esto es asi, si ellas identifican un concepto para nosotros.

(a) No sé si haya condiciones generales que determinen o no si una frase se refiere a un concepto. Lo que sí sé es que una condición necesaria para la posibilidad de un concepto es que no sea lógicamente contradictorio predicar de una entidad la empirisidad y la mismidad.

(b) Soy lo bastante empirista para creer que es una verdad necesaria el que haya conceptos no a priori de entidades empíricas, esto es, conceptos que sean derivados a partir de la experiencia.

(II) Uno se puede preguntar si este concepto - asumiendo que es posible- tiene alguna aplicación actual. Por reducción al absurdo suponemos que no hay yos empíricos, y suponemos que esto es una verdad necesaria, ello implica que el concepto del yo empírico es contradictorio, lo cual contradice nuestra suposición inicial.

Para que cualquier entidad sea clasificada como 'yo empírico' debe satisfacer dos criterios: (A) Debe ser clasificable como una entidad empírica y (B) debe ser clasificable como 'yo'. Éstas constituyen sólo las condiciones necesarias, otra condición muy importante es ver si reflejamos que el uso de la frase 'el yo empírico' implica -como Russell mostró- que hay precisamente sólo un yo empírico. En los contextos normales esto implica que a cada persona o ser humano individual se le asigna sólo un yo empírico. Para ello no es suficiente mostrar que cada persona posee sólo un yo empírico - suponiendo que se pudiese mostrar-, además se debe mostrar que ninguna persona posee una pluralidad de tales yos. Considero que al menos dos condiciones se deben satisfacer para que una entidad sea clasificable como 'empírica': (i) que sea identificable por métodos empiricos y (ii) que sea identificable con otra entidad empírica - aun cuando esta última sea sólo sí misma.

(B) Para que una entidad sea clasificable como yo debe (1) ser continua durante cierto periodo de tiempo; (2) debe poseer una entidad individual -ser individualizable-; (3) debe sufrir cambio, o ser capaz de sufrir cierto tipo de cambio durante un periodo de tiempo, y (4) debe poseer conciencia en tiempos especificables 
y durante ciertos periodos.

(1) La existencia de esa entidad debe ser continua durante un cierto periodo. La función lógica del concepto de sí mismo consiste en ser un concepto inter alia, es un principio por el cual se asignan diferentes eventos a un mismo 'focus', es un principio para coleccionar eventos $y$, tal vez, es también un principio para individualizarlos.

(2) El yo empírico debe poseer una entidad individual. Los criterios para individualizar al yo juegan un doble papel: (i) sirven para individualizar cada yo como el particular yo que es y (ii) sirven al mismo tiempo para identificarlo distinguiéndolo de todos los demás yos.

Sostengo la tesis de que el concepto del yo es el concepto de una entidad cuyos criterios de identificación se basan en sus actos empíricos. La entidad referida por tal concepto se individualiza por sus actos. La relación del yo con sus actos es un caso de la relación general entre la esencia y la apariencia.

(3) El que el yo empírico sufra cambio o sea capaz de sufrir cambio durante un periodo dado de tiempo implica tres cosas: a) Que al yo le debe ser permitido crecer durante el tiempo. b) Se le debe permitir, tal vez, crecer dentro de un yo partiendo de la condición de un no yo. c) Se le debe permitir evolucionar en el tiempo. En relación a los criterios para el desenvolvimiento del yo hay que mencionar tres: 1) Algunos caracteres pueden aparecer y otros desaparecer. 2) Se deduce que podemos hablar de identidad, esto es, que debe haber continuidad identificable de caracteres. 3) Debe haber un principio que ligue caracteres nuevos al antiguo yo. Con respecto a lo anterior adoptamos el principio de potencialidad y actualización de potencialidades de Aristóteles que nos es útil.

(4) La afirmación más importante en relación al yo es que el yo debe poseer conciencia, la cual es temporal en dos sentidos: la conciencia existe en ciertos tiempos y existe durante ciertos periodos. Solamente cuando un ser posee conciencia puede ser concebido como un yo empírico. Ya que sólo en tanto un ser tiene conciencia se le puede asignar un principio de individuación. Un ser que posee mismidad posee necesariamente conciencia de sí mismo. Considero que el concepto del yo empírico es formalmente el concepto de un principio de asignación de ciertos fenómenos - de cierta selección de fenómenos relevantes - a un foco.

(1) La pregunta sobre la continuidad del yo se torna en la pregunta sobre la 'continuidad' de cierto tipo de principio unificador $y$ explicador del comportamiento personal.

(2) La pregunta por la identidad del yo se torna en la pregunta 
para proveer los criterios para la identificación de tal principio explicatorio y unificador.

(3) La afirmación sobre la evolución temporal del yo ahora se torna en la afirmación de que un cierto principio de explicación es esencialmente capaz de tal evolución.

(4) Si el concepto del yo es un principio por el cual se asigna y se explica el comportamiento de un ser esencialmente consciente, se torna claro el por qué de la tentación de identificar el concepto del yo con la conciencia, ya que en muchos casos (pero no en todos) la conciencia nos sirve para explicar los fenómenos corporales. 